\title{
PLANNING RESOURCE ROOMS FOR THE MILDLY HANDICAPPED
}

\section{RESOURCE ROOMS FOR THE MILDLY HANDICAPPED}

\section{J. Lee Wiederholt ${ }^{1}$}

Historically, children with learning problems have received two distinct types of service arrangements in public schools-regular education or special education. For the most part if a child's learning problem was viewed as significantly interfering with his school achievement, he was labeled "mentally retarded," "emotionally disturbed," "learning disabled," "deaf," "blind," etc., and placed in a self-contained special education classroom. If on the other hand the learning problem was viewed as mild, the child would remain in the regular classroom, in most cases without special education support. Unfortunately, this "either/or" situation did not account for those children who might be able to profit from the services of both the special and regular education programs.

Recently, however, an addition that attempts to bridge the gap between special and regular education has been added to this service system. This variation is most often called a "resource room." A resource room is basically any special education instructional setting to which a child comes for specific periods of time on a regularly scheduled basis for remedial instruction. The key difference between a resource room and a selfcontained special class is that the child attends the resource room only on a part-time basis, remaining for at least a portion of the day in his regular classroom. The type of remedial instruction the pupil receives is based upon his identified learning weaknesses, an individually planned and implemented instructional program geared to ameliorate or minimize his problems, and/or consultant support to the child's regular classroom teacher regarding his instruction in that system.

The growth of these resource rooms in the last few years has been phenomenal; yet many teachers and administrators remain uncertain regarding the implementation and operation of these programs in the schools. In this article, some suggestions are made concerning start-up practices and daily operation procedures.

1. Dr. Wiederholt is Program Associate in the Leadership Training Institute in Learning Disabilities and Assistant Professor of Special Education, Department of Special Education, College of Education, University of Arizona.

- Love Publishing Company, 1974. 


\section{START-UP PRACTICES}

Careful pre-planning is necessary for the successful implementation of a resource program in an individual school. The following matters need to be considered:

1. Preparing the school staff

2. Selecting a resource model

3. Selecting a resource teacher

4. Establishing communication channels

Some general guidelines are suggested relative to these points.

\section{Preparing the School Staff}

As with most innovations, there will be some resistance to this "new" program. Regular classroom teachers may be somewhat hesitant to accept problem children in their classrooms; special education teachers may be resistant to changing their roles; and administrators may cast a somewhat jaundiced eye at this new "panacea." In addition, some parents may be unwilling to expose their children to the program. This includes not only the parents of mildly handicapped children who desire extensive special help but also some parents of "normal" children

FOCUS ON EXCEPTIONAL CHILDREN is published monthly except June, July, and August as a service to those concerned with mentally retarded and emotionally disturbed children. This journal is abstracted and indexed in Exceptional Child Education Abstracts. Subscription rates, $\$ 9.50$ per year. Copyright 1974, Love Publishing Company. All rights reserved. Reproduction in whole or part without written permission is prohibited. Printed in the United States of America. Second class postage is paid at Denver, Colorado.

Executive and Editorial Offices

6635 East Villanova Place

Denver, Colorado 80222

Telephone (303) 757-2579

\section{EDITORIAL BOARD}

Edward L. Meyen University of Kansas

Richard J. Whelan

University of Kansas Medical Center

Sallie Carmachel Keeney Managing Editor
Stanley F. Love Publisher who may be reluctant to have their child educated with "deviant children." For this reason, professionals implementing the resource programs must be equipped with objective information to present to resistant people regarding the rationale of this particular type of service system.

Well-documented rationales for change within special education have been presented by Dunn (1968), Lilly (1970), Iano (1972), Christopolos and Renz (1969), Ross, De Young and Cohen (1971), Hammill and Wiederholt (1972), and Garrison and Hammill (1971) among others. These authors have expressed concern regarding a variety of inadequacies in special education which include inappropriate and invalid testing, the lack of positive efficacy research regarding self-contained special classes, the mislabeling and misplacing of many exceptional children, the fact that minority discrimination practices exist in special education, and the lack of alternatives in providing educational support to exceptional children.

After becoming familiar with these references, someone must be selected to "present the case for the resource room" to staff and parents. In most cases, it is preferable to choose someone from within a given school rather than an outside "expert." As outsiders will not be around to confront the daily problems that arise from instituting changes, teachers are justifiably concerned about receiving continuing support in the endeavor. For the most part the building principal is a logical choice, and enlisting his aid also insures his administrative understanding and cooperation in the endeavor.

Those advocating this change must stress that resource rooms are not meant to supplant all self-contained special classes. While some special classes may be disbanded and resource rooms established in their place, some selfcontained units must continue to operate to serve those children who are not able to profit from even part-time placement in a regular classroom. However, as Deno (1970) and Reynolds (1962) have pointed out, there is a need for more resource rooms than self-contained classes because there are more children with mild handicaps who can profit from regular classroom placement with support than there are those with more severe disabilities who require isolated settings.

Objective information, therefore, needs to be presented to those involved with any changes in the special education system. In the case of the resource room, this would include both regular and special education teachers and parents. The person selected to share this information should be someone who will continue to be directly responsible for the operation of the resource rooms other than the resource teacher. In addition to presenting the 
rationale for the resource rooms, the discussion should also include information concerning the type of resource rooms to be implemented.

\section{Selecting a Resource Model}

Prior to implementing a resource room, decisions must be reached on the nature of that model. Two very different models currently exist-the categorical model and the noncategorical model.

When using the categorical model, the resource room services are reserved for children who satisfy a particular disability label. For example, one resource room may be set up for educable mentally retarded youngsters. This room provides support in a given school for children with "borderline intelligence" who have some skills which allow them to function in the regular classroom with supportive help. The stated purpose of this "mentally retarded resource room" is to aid and support mentally retarded children in the regular classroom.

On the positive side, the categorical model conforms fairly well to existing state laws and regulations as well as historical precedence in special education. Many educators, administrators, teachers, parents, and legislators are simply more comfortable with this model. Programs of this nature have been described by Barksdale and Atkinson (1971) for the educable mentally retarded and by Glavin, Quay, Annesley, and Werry (1971) for the emotionally disturbed.

However, the categorical resource room has several drawbacks. First, since resource rooms are for the mildly handicapped, the necessity of labeling children with socially stigmatizing terms such as "mentally retarded," etc., is questionable and probably harmful as well. Second, the resource room continues to bear the same stigma as the special self-contained classes. It is still known as the "retarded" or "disturbed" room, or even by more derogatory names. Third, it is extremely difficult to diagnose accurately children who evidence mild to moderate problems. The learning disabled, emotionally disturbed, disadvantaged, nonmotivated, borderline intelligent, and poorly taught children all appear pretty much alike. Finally, all categorical resource teachers teach reading, math, spelling, handwriting and acceptable behavior regardless of the disability group they serve. Therefore, the categorical resource rooms appear to be more of an administrative convenience than an actual benefit to mildly handicapped pupils.

The noncategorical resource room, however, is designed to meet the educational needs of all pupils in a school, not just those who can "fit" a special education label. Any child from a regular or another special education class who is having difficulty in school work or adjustment can be referred to this setting for periods of time without having to satisfy any existing category. Psychological evaluations are not necessary to make a placement, thereby freeing the psychologists to work with the more severe cases. As a result, the focus of evaluation in the noncategorical resource room is educational. Specific disabilities in reading, spelling, behavior, etc., are pinpointed; and remedial programs are planned to aid the child in successful school performance.

Stigmatization is minimized as children are not given a label, such as "mentally retarded," which may follow them through life. Children coming to the resource rooms may be mildly mentally retarded, emotionally disturbed, or learning disabled who need individualized education for a period of time. In addition the gifted child, an unfortunately largely ignored population, is also eligible for resource help, thus diminishing the negative connotation that could accompany this special service. Reger and Koppmann (1971) and Hammill and Wiederholt (1972) have described models of the noncategorical variety.

In the noncategorical model, decisions regarding who needs resource support remains with the individual school personnel. Referrals for outside testing are not essential, thereby diminishing the time between referral and service. Resource support is planned to some extent using the viewpoints and bpinion of the personnel who are most familiar with the individual child.

Funding is a problem in the noncategorical model. As children are not given psycho-medical labels, there is in reality no special funding base. Some of these programs can be funded as "experimental," but every effort should be made to reorganize funding procedures so that this model will be reimbursable in the regular budgeting procedure.

Responsibility for financial reimbursement for resource support for children with mild problems is currently being assumed in most cases by special education. Funding, however, should be assumed by regular education alone, or at least jointly with special education. First-hand experience has indicated that children being served by resource personnel are more "normal" than they are "deviant." A child who has a reading disability, for example, may or may not be handicapped. His problem may be more in areas of teacher incompetency, lack of flexibility in regular. educational programming, or other "system defects" rather than "child defects."

Once funding is changed, teachers who are selected as resource teachers need not be special educators. There are 
many regular classroom teachers who, with some in-service, would be able to function as resource teachers. The same holds true for reading teachers, speech therapists, etc. Some criteria for selecting a resource teacher are discussed in the next section.

\section{Selecting a Resource Teacher}

In many cases, self-contained special classes are being disbanded and resource rooms are being instituted in their place. In other cases where special services are minimal or nonexistent (such as in the case of children with learning disabilities), resource rooms are being developed rather than self-contained classes.

In the first instance, the teacher simply changes his focus and becomes a resource teacher. Some in-service is usually made available to these teachers to help in their transition. The success of this practice depends upon the initial competence and the acceptance of the new role by the teachers as well as upon the effectiveness of the in-service training. In the second case, where a new teacher is selected, he probably will not have had prior tgaining to operate in this role but with, some in-service thining is viewed as being capable of functioning in this rc e. There are a few teachers who have had resource experience or university training, but the rapid expansion of this model has not yet been met with equal growth in training programs.

Regardless of how the resource teacher is selected, he must possess several competencies and have at least one important "personality characteristic." This characteristic is the ability to work effectively with colleagues. In the past, we have noted some of the difficulties in communication that arise between the resource teacher and the regular education teachers concerning children who are shared. Classroom teachers in the past have been rather autonomous regarding individual children's total curriculum or at least regarding one aspect of their education, such as reading, arithmetic, social studies, etc. Because of the shared responsibility in some content areas, the resource teacher must be able to efficiently communicate the need for and facilitate change in programming in the regular classroom.

Resource teachers must also be able to deal with specific requests from regular classroom teachers regarding the instruction of individual pupils. In cases where these requests are logical, there is little problem; however, any resource teacher will experience some illogical requests.
For example, in my experience one elementary regular education teacher insisted that a child be taught "algebra" in the resource room because his peers in the regular classroom were learning algebra. Unfortunately, the child in question did not know his basic addition and subtraction facts. In another case, a junior high teacher requested that a child write a paper on "Corinthian Columns" in the resource room despite the fact that his reading level was at the first grade level. In both cases, explanations to the regular classroom teacher did not result in a change of attitude; rather they became even more adamant. The resource teachers had to change their planned remedial programs and help the pupils complete the requests in as short as time as possible and then teach them what they thought was more important. ${ }^{2}$ This, of course, frustrafed the resource teacher.

As a result the resource room teacher will have to be highly skilled in public relations, as the success of his program depends in no small part on the support of the regular classroom teachers. Where this support is absent, the resource teacher will have to overcome many problems before the operation can be successful.

In addition to the ability to work effectively with colleagues, the resource teacher needs to be competent in at least two other areas. First, he must be able to do most of his own educational and behavioral assessment. Second, he must be able to successfully develop and implement individualized programs. Some general guidelines regarding these skills are discussed later in this article under Assessment and Remediation.

In summary, to perform adequately in the resource model, the teacher must possess three particular kinds of ability. First, he must be able to work closely and harmoniously with other teachers and ancillary staff. Second, he must be able to assess specific educational and behavioral problems and needs. Third, he must be able to design and implement individualized instruction for children referred to the resource room. The most effective resource teachers will be those who have these basic skills. In addition, these necessary skills can be markedly enhanced if proper communication channels have been established in the school prior to implementing the resource room.

2. It is interesting to note that even with the resource teacher's help the junior high student received a " $C$ " on his "Corinthian Columns" paper. 
Establishing Communication Channels

Once the staff has been informed that resource rooms are to be set up in the school, there is a need for insuring initial and continuing communication flow. In the beginning there is always some confusion regarding such policy matters as referrals and scheduling. How the child is referred and to whom he is referred often are confusing when there are other ancillary personnel in a given school (such as a counselor, nurse, reading teacher, team leaders, vice-principals, speech therapist, etc.), and remedial roles become confused. In other schools the resource room may be the only available supplemental support, and as a consequence the confusion will be somewhat diminished.

As a supervisor and coordinator of resource rooms for Temple University and the Philadelphia Public Schools, I found that appointing a resource team was of benefit in facilitating communication flow. One hour was set aside for a team meeting once a week. Members of the team meet before or after school, during lunch (brown-bagging it) or, if aides are available, during the school day. Members of this team include the resource teacher, any regular classroom teacher who has a child to be discussed during that specific meeting, and all other ancillary personnel such as those previously specified. Two points regarding team members are most important. First, the principal of the school should probably be the resource team chairman. He is the one to make the final decision. regarding the type of resource service an individual child is to receive. If the resource teacher acts as team chairman, then he becomes the final decision-maker and the one who takes the responsibility for making unpopular decisions. Because of the necessity of his being able to work efficiently on a one-to-one basis with other teachers in the school, he would be an unwise choice as a team chairman. In addition, some decisions ultimately need to be made and supported by the principal; and his being team chairman necessitates that he attend each meeting.

The specific purposes of these meetings are to discuss the treatment of children for resource support, a periodic progress report on the success of individual children, and other problems that arise from time to time. Usually, children who have been referred by the regular classroom teacher are discussed. These referrals should go to the principal who, in turn, gives the referral to the resource teacher who then makes a classroom visit to observe the child functioning in the regular grade. Giving the referral to the principal first enables him to keep track of who is referring children and who is not, as well as who is over-referring children (the over-referring teacher will probably need some help of a consulting nature). The specific steps in implementing this team approach are as follows:

1. A team consisting of the school principal, regular classroom teachers, resource teacher, and ancillary school personnel is appointed. The team is made up of in-house rather than district personnel, as the purpose is not labeling children but rather working out an individualized program based upon existing school resources. Initially, this resource team meets weekly. When the resource teacher achieves a full caseload and the resource room is fully operational, meetings may be less frequent.

2. Three copies of the referral form are given to each teacher in the school together with specific instructions regarding completing the form and sending it to the principal. During the initial implementation of the program, the form should be clear, concise, easy to fill out and should include factors such as the child's level of performance of basic academic skills, his ability to profit from group instruction, his classroom behavior, and any additional comments the referring teacher may care to make. As the resource model becomes better understood and operational, more detailed information on the referral form may be requested.

3. The principal records, makes written comments, and passes along the referral form with the school records of the child to the resource teacher.

4. The resource teacher observes the child in the regular classroom and compiles information regarding his present and past performance.

5. The team meets and decides upon the best program for the child. Some decisions that may be made are as follows:

- Should a psychological or medical examination be given?

- Is the child's problem of such a mild nature that the resource teacher can do an assessment, e.g., informal arithmetic inventory?

- Is the child's problem of such a nature that his program should be implemented by other than the resource teacher, e.g., reading teacher, counselor, social worker, speech therapist? 
- What type of support does the regular classroom teacher need?

- Periodic reviews of the achievement of individual children.

- Any additional problem that needs a team decision.

The success of these team meetings rests for the most part on the resource teacher. He needs to be aware of the existing resources, to plan the agenda for the meetings, and to be able to offer pragmatic suggestions regarding placement and programming decisions.

This group decision-making removes much of the conflict that a resource teacher might encounter if he dealt directly with regular classroom teachers regarding the programming for individual children. In addition both the resource and regular classroom teachers are "peers" in making contributions regarding individual children, and plans are made by the group concerning their specific interaction for a given pupil in the future.

Personal experience has indicated that the team, in addition to making decisions about mildly handicapped children, also begins to deal with issues such as inadequate resources available within a, school, modifications of existing curriculum in the classroom, parents' support, etc. The resource room then becomes the center for educational support for problem pupils as well as for changing a variety of school practices.

\section{Summary}

The advantages of the resource room apptoach for mildly handicapped pupils, the school, and the teachers can be enumerated as follows ( 1 to 6 pertain to resource rooms in general; the remainder are more likely to be associated with noncategorical resource rooms):

1. Mildly handicapped pupils can benefit from specific resource room training while remaining integrated with their friends and age-mates in school.

2. Pupils have the advantages of a total remedial program which is prepared by the resource teacher but may be implemented in cooperation with the regular class teacher.

3. Resource rooms are less expensive as the teachers are able to serve a greater number of children than special class programs.
4. More children's needs can be served under the resource room arrangement than can be served by the present system.

5. Since the resource teacher is assigned to a particular school (unlike some school psychologists, remedial reading therapists, speech correctionists, or other itinerant staff), he is less likely to be viewed as an "outsider" by other teachers in the school. In addition, he probably better understands the programming problems in a particular school.

6. Because young children with mild, though developing, problems can be accommodated, later severe disorders may be prevented.

7. Because disability diagnoses are not necessary for placement purposes, pupils are not labeled in any way as handicapped.

8. Because labeling and segregation are avoided, the stigma invariably associated with receiving pecial attention is minimized.

9. Since most schools are large en $/$ agh to accommodate one or more resource rooms, plpils can receive help in their neighborhood school.

10. Pupils are the recipients of flexible scheduling in that remediation can be applied entirely in their classrooms by the regular teacher with some resourci teacher support or in the resource room itself when necossary; also the schedule can be quickly altered to meet the children's changing situations and needs.

11. Because placement in the resource room is an individual school matter involving the principal, the teachers, and the parents, no appreciable time lapse need occur between the teacher's referral and the initiation of special services for the child.

12. Under this alternative, medical and psychological work-ups are done only at the school's request rather than on a screening-for-placement basis; thus, the school psychologist is freed to do the work he was trained to do instead of being relegated to the role of psychometrist.

13. Since the resource room will absorb most of the "handicapped" children in the schools, the special classes will increasingly become instructional settings for "truly" handicapped pupils, i.e., the children for whom the classes were originally intended. 
14. Because of the resource teacher's broad training and experience with many children exhibiting different educational and behavioral problems and varying maturational levels, he is likely to become an "in-house" consultant to his school.

To conclude, the resource room model appears to be a promising instructional alternative deserving of the continued interest of educators. Its use may well enhance the education of both handicapped and nonhandicapped children with learning and behavior problems, especially those with mild to moderate difficulties. However, as anyone with first-hand experience in this area can avidly testify, the model is no panacea or "Promised Land." For the resource room model to work successfully, considerable public relations, tact, administrative support and, most of all, teacher competence are required. Neither is the model a substitute for special education disability classes. Some children are so unmanageable or have such commanding instructional problems that their assignment to a regular class would be inadvisable. In any event, we are likely to witness the widespread growth of resource rooms in one form or another within the next few years; hopefully, many of them will be implemented on a noncategorical basis (Hammill \& Wiederholt, 1972).

\section{OPERATING PROCEDURES}

Once the individual school staff has been prepared for the resource program, the model and teachers selected, and communication channels clearly established, some additional daily operating procedures are recommended. These include assessment and remediation and the organization of the resource rooms.

\section{Assessment and Remediation}

Screening for admission into the resource room has been described earlier in this article under Establishing Communication Channels. Referral forms that are clear, concise, and easy to fill out are given to regular classroom teachers who submit the referral forms to the principal. A team of school personnel meets to discuss the next step in providing service to an individual child. If financial reimbursement rests upon the fact that a child must fit a given special education category, psychological and/or medical exams might be requested. Hopefully, for the mildly handicapped, this process can be circumvented; and educational assessment and scheduling can be the focus of the decision making.

When educational assessment is viewed as the next step in planning a remedial program, the resource teacher is the logical choice to administer and interpret selected tests. It is important that a battery of standardized tests not be routinely administered to children in educational assessment. This process represents an expensive and inefficient use of the resource teacher's time, increases the interval between referral and services and, in many cases, yields educationally useless information. For example, if the team agrees that the child's major problem appears to be reading, then an appropriate reading test should be administered. If, as in the case of younger children, reading is taught as a formal curriculum process, then the reading test employed should tap out those skills the child is expected to have in the reading series employed in the regular classroom, e.g., Banks Basic Reading Series, Ginn 360 etc. It is important to remember that the purpose of the resource room is to keep children in the regular classroom, and it is simply ineffective not to consider the curriculum of the regular classroom in selecting assessment techniques. If reading is taught by phonics in the regular classroom, then a phonics test should be given, not a word-recognition test. The same holds true for the other curriculum categories.

In assessing behavior disabilities, the regular classroom teacher needs to be consulted regarding what he views as the individual child's most severe specific behavior problem (e.g., talking out, fighting, inattention, passivity, etc.). The more specifically the problem can be stated, the more specifically the remedial program can be developed and implemented. As in educational assessment, the resource teacher needs to keep in mind that the purpose of the resource room is to keep the child in the regular classroom.

The second step is to utilize the specific assessment information derived and plan an individualized program of remediation to be implemented by the regular classroom teacher, the resource teacher, or a combination of both. As in assessment, this plan should be directed toward helping the child secure information he needs to successfully remain in the regular classroom. If, as in the previously mentioned case, the child is being taught phonics, the remedial program should be phonic in nature, possibly even with existing regular classroom materials presented again, individually, to the child.

Careful analysis of the daily or weekly progress of the child in the remedial activities should be noted. Where progress is not being made, additional manipulation of the 
curriculum should be made, such as the use of more specific and smaller instructional units presented with reinforcement. If the child still does not make progress, more detailed assessment of reading difficulties will need to be made. Informal standardized reading tests such as the Durrell Analysis of Reading Difficulties or other devices can be given. If through continual testing/remediation the child still is not making progress and if the resource teacher believes he needs a very specific, different-fromfthe-regular classroom reading instruction (e.g., the Gi ingham or Fernald program), then a referral to another tervice class possibly should be considered, as these latter highlystructured programs take a great deal of time and expertise to teach. However, a resource teacher should not conclude that because a child is referred he canno learn and progress in the existing regular classroom currictilum.

Regarding educational assessment/remediation, many resource teachers are extremely concerned about auditory and visual perceptual disabilities as well as psyc dysfunctions. This is hardly surprising cons lering the preoccupation of some educators, psycholog ts, physicians, optometrists, and parents with these prolesses. This interest is one of the most remarkable phenormena occurring in special education during the last 15 years. As a consequence, many perceptual-motor and psycholinguistic tests and training programs, ranging from hitghly standardized tests and sequenced instructional packages to informal assessment procedures and loosely structured collections of activities, have been developed.

After a decade and a half of extensive testing, instruction and research, some professionals have togun to question if the allocation of time, the exp nditure of funds, and the untold efforts of children and teachers have been worthwhile. After careful examination of the literature that has accumulated over the last several years on the relationship of selected auditory perceptual skills and reading ability (Hammill \& Larsen, 1974), on the efficacy of psycholinguistic training (Hammill \& Larsen, 1973), on the success of training visual-motor perceptual processes (Hammill, Goodman \& Wiederholt, 1974), and on the effect of learning meaningful and nonmeaningful material by auditory and visual learners (Newcomer \& Goodman, 1974), these authors have concluded that the validity of these techniques simply have never been clearly established. As a result, the usefulness of process and perceptual programs by resource teachers is questionable. Adding to the efficacy researeh the fact that the purpose of the resource room is to maintain children in the regular classrooms makes such programs as an integral part of mainstreaming instruction for most mildly handicapped children extremely inadvisable. Curriculum in the resource room for individual children should be as closely related as possible to the curriculum in the regular classroom, which is rarely of a structured perceptual or process nature.

Therefore, the assessment/remediation process by resource teachers needs to focus upon what skills the child needs to know in order to function in a specific regular classroom. Criteria for selection of assessment techniques and remedial programs are based upon the regular classroom instruction. Only if a child continues to fail after adaptations of the existing curriculum are other assessment/remediation procedures selected. For a few children it is possible that the remediation program ultimately chosen will be far removed from the regular curriculum, but every attempt should be made to move the pupils as quickly as possible to those activities utilized by the regular classroom teacher. In order to accomplish this assessment/remediation process efficiently, there needs to be a carefully planned organization of the resource room.

\section{Organization of the Resource Room}

Inherent in the discussions throughout this article is the need for a set plan in the organization of the resource teacher's time and classroom. As noted throughout, the resource teacher needs periods of time for assessment, remediation, and consultation in order to be effective. During the initial stages of program development, at least one hour per day should be set aside for consultation, one hour for assessment, and one hour for program planning. In total, approximately half of the school day is not devoted to actual remedial instruction with individual pupils. In addition, Hammill and Wiederholt (1972) have recommended that during the first two or three weeks of school no pupils should be assigned to the resource room. This delay allows for (1) reevaluation of pupils who have been designated as handicapped the previous year and are likely to need resource support, (2) the regular classroom teachers to modify their programs to accommodate the mildly handicapped pupils, and (3) the resource teacher to analyze the regular classroom programs with emphasis on acquiring and/or developing related assessment and remediation devices.

After the first few weeks, children can begin to be slowly scheduled into the resource room. As the assessment and emediation programs are planned and implemented an evaluated as successful, more mildly handicapped youngsters can be added from time to time to the resource room program. ${ }^{3}$ Aides (paraprofessionals, parents, 
or bright pupils) are extremely beneficial in increasing the number of children who are served in the resource room. They should be considered quite seriously whenever possible.

These recommendations should be considered in planning the time allocations for the resource teacher during the initial stages of the program. However, as the program becomes operational, more flexible scheduling of time will develop naturally. For example, the resource teacher may be so skilled at consultant support that it may be simply more profitable for the mildly handicapped pupils that he work closely with the regular classroom teachers:Another resource teacher may find for a variety of reasons that there is some resistence by the regular education staff to consultant support and may find it more expedient to work in the resource room with selected students.

The beauty of the resource room program is its inherent flexibility. This flexibility allows these programs to integrate into a school rather than requiring the school staff to adjust their programs to this new model. The scheduling of the resource teacher's time is based upon an individual school's actual needs and assets rather than a global preconceived notion of that school's need in the form of resource support.

While this flexibility may appear to allow the resource teacher to be unaccountable for his time and activities, this is far from the truth. He is being watched and monitored carefully by the regular classroom teachers, and they will be the first to note his success (or failure) in aiding the education of handicapped children within the mainstream. When problems arise, ways should be found to reallocate the resource teacher's time to better meet the needs of problem children.

The accountability of the resource teacher to regular classroom teachers may present a problem during the initial implementation of the program. This is particularly true when the resource program has been introduced in glowing terms and offered as the "Promised Land." Educators, particularly those planning the changes, have a tendency to approach innovations with a missionary-like zeal. The resource room, despite the claims of some of its proponents, is not a panacea. It is simply an administrative

3. The number of children served will vary from teacher to teacher. Some teachers will be able to deal successfully with a great number of students because of his skill, the regular classroom 'teachers' support, and the mild nature of the referred children. In other cases, a much smaller number of students will be able to be successfully supported because of the absence of one or more of the above factors. The focus should be upon the words "successful support," and this should not be sacrificed for specified quantity. arrangement that appears necessary and viable for the 1970 s in the American educational system. The point here is that because of the accountability of the resource teacher to the regular classroom teachers the proponents of this approach should not promise too much when introducing this system. When expectations are too high, only disappointment and dissatisfaction can result.

In addition, the variety of activities as well as the numbers of children served necessitates some planning as to the organization of the resource room itself as well as the equipment that facilitates efficient instruction. Note some of the following equipment and its general uses:

1. Desks for group activities and individual study areas. While the focus of the resource room is on individualized instruction, seldom will it be occupied only by the teacher and one child. Some children may be receiving direct help from the teacher, while others may be involved in independent activities that reinforce individual instruction. As a result, a place should be set aside for one-to-one instruction, one-to-three or five instruction, and individual study areas. Usually, the pupil's desks found in any school will suffice with the addition of large tables. Booths are excellent but sometimes too expensive for individual study areas. Creativity by utilizing existing materials can be applied in establishing these areas. Regular classroom desks partitioned off by bookcases, portable chalkboards, etc., are easy to create and arrange. Also, large pieces of cardboard may be taped to desks to insure privacy and to enhance attending behavior.

2. File cabinets. The organization of a number of worksheets, pupil folders, testing materials, etc., is facilitated by a file cabinet where teachers can efficiently store and retrieve necessary materials. Where monies are not available for file cabinets, cardboard boxes can be utilized. Any materials developed by the teachers then can be copied and filed for future use when appropriate.

3. Tape recorder and headsets. In facilitating individualized instruction, it is helpful for the resource teacher to record stories, questions, or directions that a pupil can listen to while doing his assignment. As any resource teacher can attest, most commercial makerials need to be manipulated for independent work. The headsets serve a dual purpose-listening to teacher made or commercially made tapes and screening out extraneous noise.

4. Regular classroom texts and materials. As the purpose of the resource room is to maintain problem 
children in the regular classroom, the resource teacher needs to have a complete set of the materials utilized in the regular system. This includes the reading, arithmetic, etc., materials which, in turn, are utilized in an individualized manner.

5. Supplemental materials. It is assumed, of course, that the resource room will be equipped with paper, pencils, etc. In addition, the teacher will probably want to supplement all of the previously mentioned materials and equipment with his own preferred programs and devices. Word cards, alphabet letters, and other materials can be selected from any number of school catalogs. The resource teacher should examine carefully the constraints of the budget and select those materials that are the cheapest and that cannot be teacher-made as well as those materials that promote mainstream success. Three-by-five cards, paper, magic markers, and creativity can and should be used where possible instead of purchasing attractively packaged, expensive commercial materials.

In this section on the organization of the resource teacher's time and classroom, some general suggestions were posited. The scheduling of time for activities focuses upon flexibility and fitting into the needs of the school and the mildly handicapped pupils. The resource room should promote individualized instruction and mainstream programming. In most cases, this demands creativity by the resource teacher. Overall, the room should present an attractive, well-organized appearance that reflects well upon the resource program for both the other school staff members and the resource pupils.

\section{CONCLUSION}

In this article, some suggestions have been made concerning initial procedures for establishing resource rooms along with some general operational guidelines. Reiterated throughout has been the premise that resource rooms should be established in a flexible manner in order to meet the needs of the mildly handicapped youngsters in a specific school and that there are no hard-and-fast rules regarding theit implementation and operation. This, however, demands a constant in-house check to determine the efficacy of the individual approaches selected.

Professionals who are interested in the possibility of establishing resource rooms should read at least some of the references cited and should visit on-going programs to see them at first hand in practical operation. They should talk with regular classroom teachers, the building principal, and some pupils as well as with the resource teacher. In particular, they should be on the lookout for shortcomings as well as the advantages of the programs visited. In so doing, they can obtain a fair picture, thereby determining just which aspects of the program it would be wise to attempt to adapt for their own schools and identifying potential difficulties that could be prevented.

As with all educational enterprises, the success of the resource room model does not depend entirely upon its inherent superiority over other approaches; the adoption of the model will not in and of itself mandate pupil achievement. Effective operation of the model depends upon the competency of the resource teacher, the cooperation and abilities of the regular teachers, the enthusiastic support of the building principal, and the availability of adequate space and materials. Where these elements are absent, thure is unavoidable; where they are present, the succèss of the effort will be insured.

\section{REFERENCES}

Barksdale, M. W. \& Atkinson, A. P. "A Resource Room Approach to Instruction for the Educable Mentally Retarded." Focus on Exceptional Children, 3, 1971 (12-15).

Christopolos, F. \& Renz, P. A. "A Critical Examination of Special Education Programs." Journal of Special Education, 3, 1969 (371-379).

Deno, E. "Special Education as Devèlopmental Capital." Exceptional Children. 37, 1970 (229-237).

Dunn, L. M. "Special Education for the Mildly Retarded-Is Much of It Justifiable?" Exceptional Children, 35, 1968 (5-22).

Garrison, M. \& Hammill, D. D. "Who are the Retarded?" Exceptional Children, 38, 1971 (13-20).

Glavin, J. P., Quay, H. C., Annesley, F. R. \& Werry, J. S. "An Experimental Resource Room for Behavior Problem Children." Exceptional Children, 38, 1971 (131-137).

Hammill, D. D. \& Larsen, S. C. "The Relationship of Selected Auditory Perceptual Skills and Reading Ability." Journal of Learning Disabilities, 1974 (in press).

Hammill, D. D. \& Larsen, S. C. "The Efficacy of Psycholinguistic Training." Unpublished manuscript (University of Texas-Austin, 1973).

Hammill, D. D., Goodman, L. \& Wiederholt, J. L. "Visual-Motor Processes: What Success Have We Had in Training Them." The Reading Teacher. 1974 (in press).

Hammill, D. D. \& Wiederholt, J. L. The Resource Room: Rationale and Implementation. Fort Washington, Pennsylvania: Journal of Special Education Press, 1972.

Iano, R. P. "Shall We Disband Our Special Classes?" Journal of Special Education, 6, 1972 (167-177).

Lilly, S. M. "Special Education: A Teapot in a Tempest." Exceptional Children, 37, 1970 (43-48).

Newcomer, P. \& Goodman, L. "Effects of Modality of Instruction on the Learning of Meaningful and Nonmeaningful Material by Auditory and Visual Learners." Journal of Special Education. 1974 (in press).

Reger, R. \& Koppmann, M. "The Child-Oriented Resource Room." Exceptional Children, 37, 1971 (460-462).

Reynolds, M. C. "A Framework for Considering Some Issues in Special Education." Exceptional Children, 7, 1962 (367-370).

Ross, S. L., De Young, H. G. \& Cohen, J. S. "Confrontation: Special Education Placement and the Law." Exceptional Children, 38, 1971 (5-12). 
RESOURCE MATERIALS

Because the concept of integrating the special child into the regular classroom currently is prevalent, considerable interest in learning centers and resource rooms has resulted. For those readers seeking practical advice regarding materials, procedures, and implementation, we present the tables of contents from two of the available books dealing with these topics.

\section{THE RESOURCE ROOM:}

\section{RATIONALE AND IMPLEMENTATION}

by Donald Hammill and J. Lee Wiederholt

Preface

Chapter I / The Need for the Resource Room Model A Traditional Special Education Program

Reasons for Modifying the Special Education ServiceDelivery System

Chapter II / The Resource Room Concept

What is a Resource Room?

Historical Perspectives Relative to the Resource Room The Categorical Resource Room

The Non-Categorical Resource Room

The Efficacy of the Resource Room Model

The Advantages of the Resource Room Approach

Chapter III / Implementing the Resource Room Preparing the School Staff

Basic Roles in Which Resource Teachers Function Competencies of Resource Room Teachers

Admission Procedures

Organizing the Resource Room Day

Reimbursement for Resource Services

Chapter IV / Summary and Concluding Remarks

References

Appendix / Selection of Instructional Materials and Equipment for Resource Rooms

For information regarding this book, contact Buttonwood Farms, Inc., 3515 Woodhaven Road, Philadelphia, Pennsylvania 19406.

\section{MOTIVATING RELUCTANT LEARNERS: A MANUAL FOR SUCCESSFUL LEARNING}

by Frank M. Taylor, Alfred A. Artuso, Frank M. Hewett

Introduction

Chapter 1 / Ideas and Materials for Use in Interest Centers Chapter 2 / Strategies and Materials for Use in Motivation, Instruction and Modification of Behavior

Chapter 3 / Daily Schedule, Curriculum and Materials for Use in a Resource Room (Engineered Classroom)

Chapter 4 / Organization of a Learning Center for Special and Regular Students (Madison School Learning Center Plan)

Appendixes / Individualized, ready-to-use tasks and activities in arithmetic, reading, art, etc.

For additional information, contact Love Publishing Company, 6635 East Villanova Place, Denver, Colorado 80222.

\section{ALERT}

The Association for Children with Learning Disabilities will hold their 1974 international conference at the Albert Thomas Convention \& Exhibit Center in Houston, Texas, on February 27, 28, March 1, 2, 1974.

The fifty-second annual international convention of the Council for Exceptional Children will be held April 1419, 1974, in New York City at the Americana and New York Hilton hotels.

Focus on Exceptional Children back issues are available. Single copy of a back issue is $\$ 1.00$, while ten or more copies of the same issue are $50_{\$}$ each.

Focus on Exceptional Children newsletter binder is now available for $\$ 3.50$. 
CLASSROOM

\section{FORLM :}

Edited by Norma Boekel

University of Northern Colorado

\section{PROBLEM 32}

I am a language arts teacher, currently assigned to remediate speaking, reading and writing problems among elementary children. Poor handwriting is a problem occurring frequently among these children. In my school there is a difference of opinion as to whether children with learning problems should be taught cursive or manuscript writing. Can you offer a solution to this argument?

Ultimately, you must resolve the argument yourselves! Initially, this highly complex form of communicationhandwriting-must be tied to a reasonable testing program for each child. You will need to diagnose factors that are interfering with learning and base your plan of action on that diagnosis. Consider (a) visual perception, (b) motor skills, (c) motivational factors, (d) visual memory, (e) previous instruction, and (f) the child's present developmental level.
According to Lerner (1971, p. 190) the arguments in favor of cursive writing are that it minimizes spatial judgment problems for the child and that there is a rhythmic continuity and wholeness that is missing from manuscript writing. Futher, errors of reversals are virtually eliminated with cursive writing; and by beginning with the cursive form in initial instruction, the need to transfer from one form to another is eliminated. Many children with learning problems find it difficult to make the transfer to cursive writing if they learned manuscript writing first.

There are several handwriting scales for evaluating a child's skill, such as Ayres Measuring Scale for Handwriting (Educational Testing Service) and the Freeman Evaluation Scale for Guiding Growth in Handwriting (Zaner-Bloser).

Good results have been obtained with instruction in both symbolic forms. Reinforcing the system the child is using in his classroom seems to be a wise strategy, if all other things are equal.

Lerner, Janet W., Children With Learning Disabilities. Boston, Mass.: Houghton Mifflin Company, 1971 (p. 190).

All readers are invited to submit questions to the Classroom Forum column. Send your questions to the Editorial Offices, Focus on Exceptional Children, 6635 East Villanova Place, Denver, Colorado 80222.

ERRATUM ... In the October, 1973, issue the publisher's name was omitted from the Minskoff, Wiseman and Minskoff reference. The correct citation is as follows:

Minskoff, E. H., Wiseman, D. E. \& Minskoff, J. G. The MWM Program for Developing Language Abilities. Ridgefield, N. J.: Educational Performance Associates (563 Westview Avenue, 07657), 1972. 